Dept. of Pathology \& Patasitology, Faculty of Vet. Med., Beni-Suef, Head of Dept. Prof. Dr. M.B. Sami.

\title{
EFFECT OF SOME DRUGS ON EGG COUNT AND BLOOD CHEMISTRY OF FASCIOLA INFESTED ANIMALS IN MID-EGYPT (With 2 Tabes \& 2 Figs.)
}

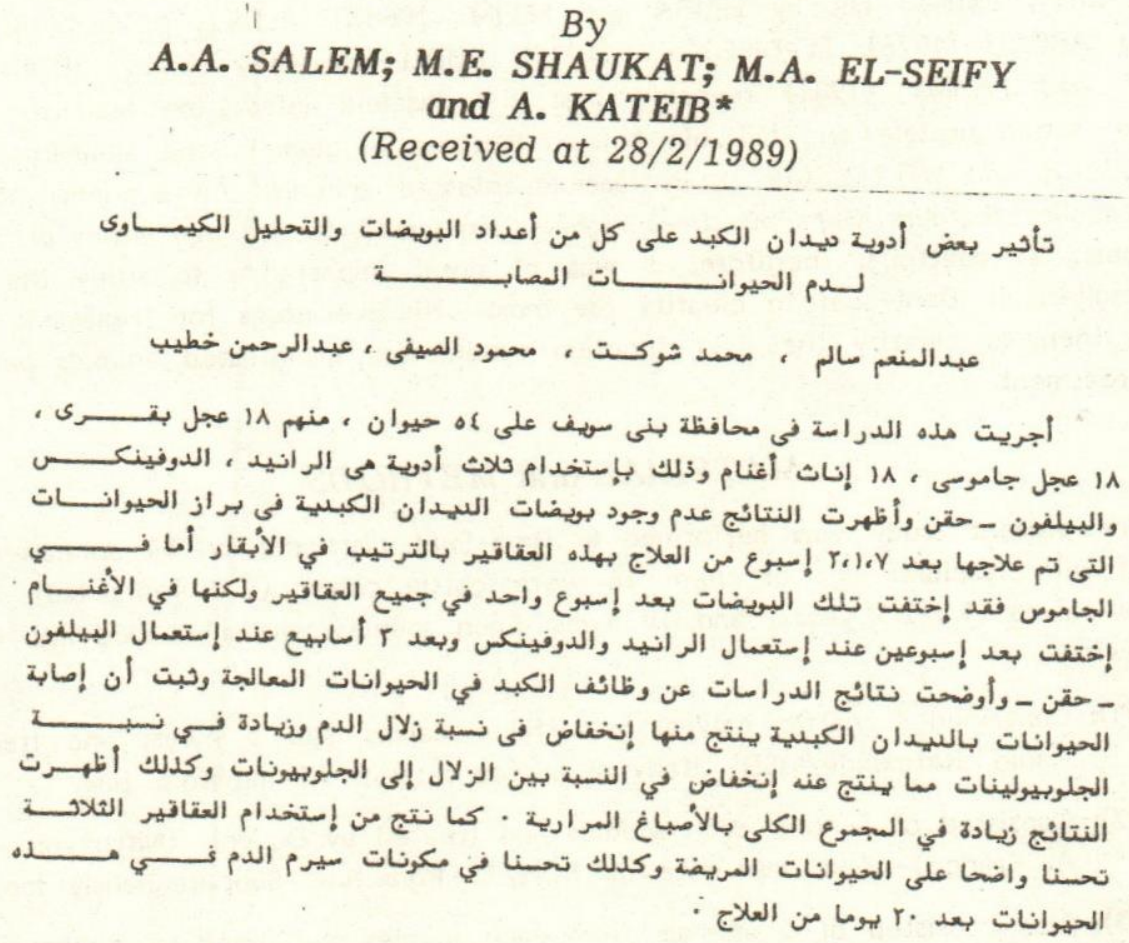

\section{SUMMARY}

The present investigation was carried out to clearify the efficacy of Ranide; Dovenix and Bilevon in treatment of Fascioliasis. The results revealed no eggs in feaces of infested animals after 2-3 weeks posttreatment. The results of biochemical studies revealed hypoalbuminaemia, hyperglobulonaemia, decrease in $A / G$ ratio and an increase in total bilirubin of blood serum of fasciola infested animals. All parameters were progressed to normal levels with the progress towards recovery.

* Dept, of Vet. Med., Beni-Suef Governorate. 


\section{A.A. SALEM, et al.}

\section{INTRODUCTION} of fasciola, AMIN (1972); AYOUB, et al. (1973); ABDEL-RAHMAN, et al. (1977) and AZIZ (1980) used Bilevon-R and Nilofolan $4 \%$ in the treatment of fasciola infestation among catle and sheep, while EL-SHERIF and FAHMY (1981) used Bilevon-injection

The studies of biochemical analysis of serum of infested cattle; buffaloes and sheep which carried out by HAIBA and SELIM (1960); TALLAT, et al. (1965); AMIN (1972); ABDOU (1976); EL-DISSOUKY (1977); ABDEL-RAHMAN, et al. (1977) and ELSHERIF and FAHMY (1981) revealed that the fasciola infestation lead to reduction in total serum protein and bilirubin but an increase in globulin and albumin. According to RIBBECK and WITZEL (1979), in fasciola infested animals, the econemic losses due to metabolic disorders were 30 times higher than lossed due to mortalities or condemuated parts in abattoirs, therefore, it was of great importance to study the problem of fascioliasis in Beni-Suef to clearify the most effective drugs for treatment of those warms, then to clearify the liver function parameters in infested animals before and after treatment.

\section{MATERLAL and METHODS}

The present study was performed in Beni-Suef distriacte on 54 animals naturally infested with fasciola. Out of them 18 were cattle calves (2-3 years old); 18 were buffaloe calves (1.5-2.5 years) and 18 ewes. Each species was subdivided into 4 groups

Group (1): Contained 5 cattle calves, 5 buffaloe calves and 5 ewes; and treated by Ranid (Rafoxnide/MSD) Orally at a dose rate of $7.5 \mathrm{mg} / \mathrm{Kgm}$. b.w.

Group (2): Consisted of 5 from each species and treated by Dovenix (Nitroxynil / S.P.E.I. A. France) at a dose rate of $1 \mathrm{ml} / 25 \mathrm{Kgm}$ b.w. Subcutaneously inoculation.

Group (3): Also consisted of 5 animals from each species and dosed by Bilevon-injection (Niclofolon/Bayer, W. Germany) Subcutaneously by a rate of $1 \mathrm{ml} / 50 \mathrm{Kgm}$. b.w.

Group (4): Consisted of 3 infested non-treated control animals from each species.

STUDIES ON EFFECT OF TREATMENT ON FASCIOLA EGG COUNT:

The feacal samples collected 3 times (in 3 successive days) from all experimental animal groups before application of the drug and in the 1st, 2nd, 3rd, 5th, 7th, 9th
and 12th week post-treatment.

The number of eggs per gramm was calculated according to method discribed by PARFIT and BANKS (1970). 
FASCIOLA IN MID-EGYPT

\section{STUDIES ON EFFECT OF SOME DRUGS ON SOME BIOCHEMICAL PARA+METERS OF BLOOD
SERUM:}

The blood samples were collected 3 times, one before and 2 after 10 and 20 days post-treatment.

The serum separated from the blood smples and kept in deep freez until use.

Determination of blood serum bilirubin by using spectrophotometer on wave length $578 \mathrm{~nm}(560-600)$ according to the method discribed by JENDRASSIK (1938).

Determination of blood serum total protein by using the same spectrophotometer on wave length $546 \mathrm{~nm}$ (530-570) according to the method of WEICHEL BAUM (1946).

Determination of blood serum albumin also using the same apparetus on wave length 578 according to DOUMAS (1971).

Determination of serum globulin by substeacting the value of serum albumin from the value of serum total protein. and globlin.

Determination of Albumin/Globulin Ratio by using the values of serum albmin

\section{RESULTS}

The results of the pressent study are shown in Table(1) and revealed that Dovenix is more effective drug as proved by complete disappearnce of fasciola eggs from the feaces of cattle and buffaloes in the 2nd week post-treatment and in 3rd one in case of sheep. Bilevon-injection resulted in disappearnce of the eggs from feaces at the end of the 3rd and 2nd week in cattle and buffaloes respectively, on the other hand the eggs disappeared from sheep feaces in between the $\underline{3 r d}$ and 5 th weeks. while in case of Ranide treatment among cattle, buffaloes and sheep, resulted complete recovery in buffaloes in the 2 nd week and 3rd one in sheep, but in cattle from the 9th week post-treatment.

Studying the effect of these fasciolicdial drugs on the liver functions revealed an increase in total protein after treatment in both cattle and buffaloes, while no changes in sheep could be detected.

Blood serum albumin was decreased in cattle treated by Ranide and Dovenix, but increased after using Bilevon-injection. In buffaloes, albumin increased as a result of treatment by Ranide and Dovenix only. On the other hand in sheep albumin was temporary decreased during the first 10 days when treated by the same drug.

Concerning the globulin $(\mathrm{gm} / 100 \mathrm{ml})$ the results indicated that the treatment of both cattle and buffaloes leading to an increase in values of glubulin in serum, in sheep this level was increased then decreased within 20 days post-treatment. Moreover, results of biochemical studies indicated variations in total bilirubin before and after treatment. 


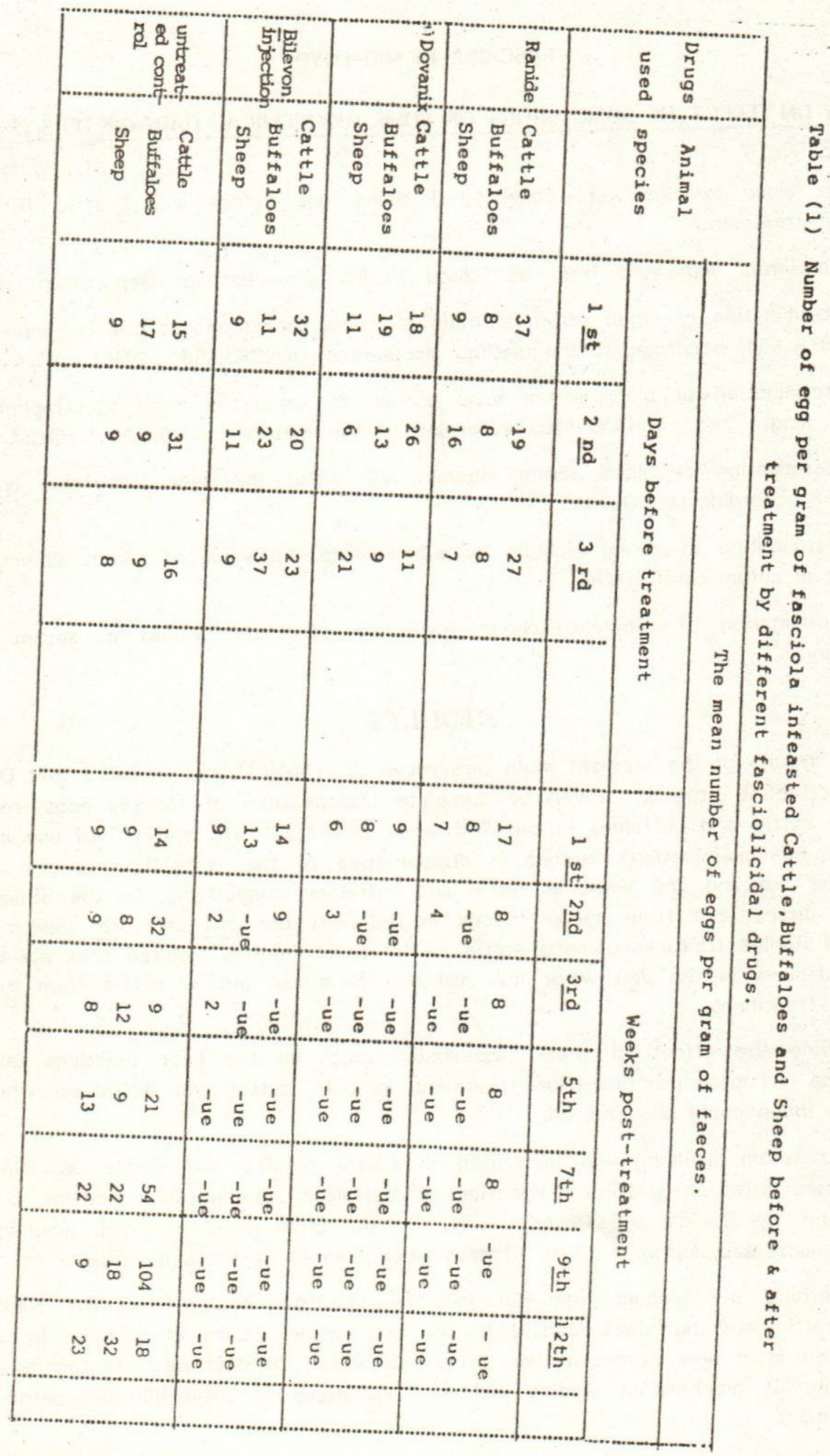




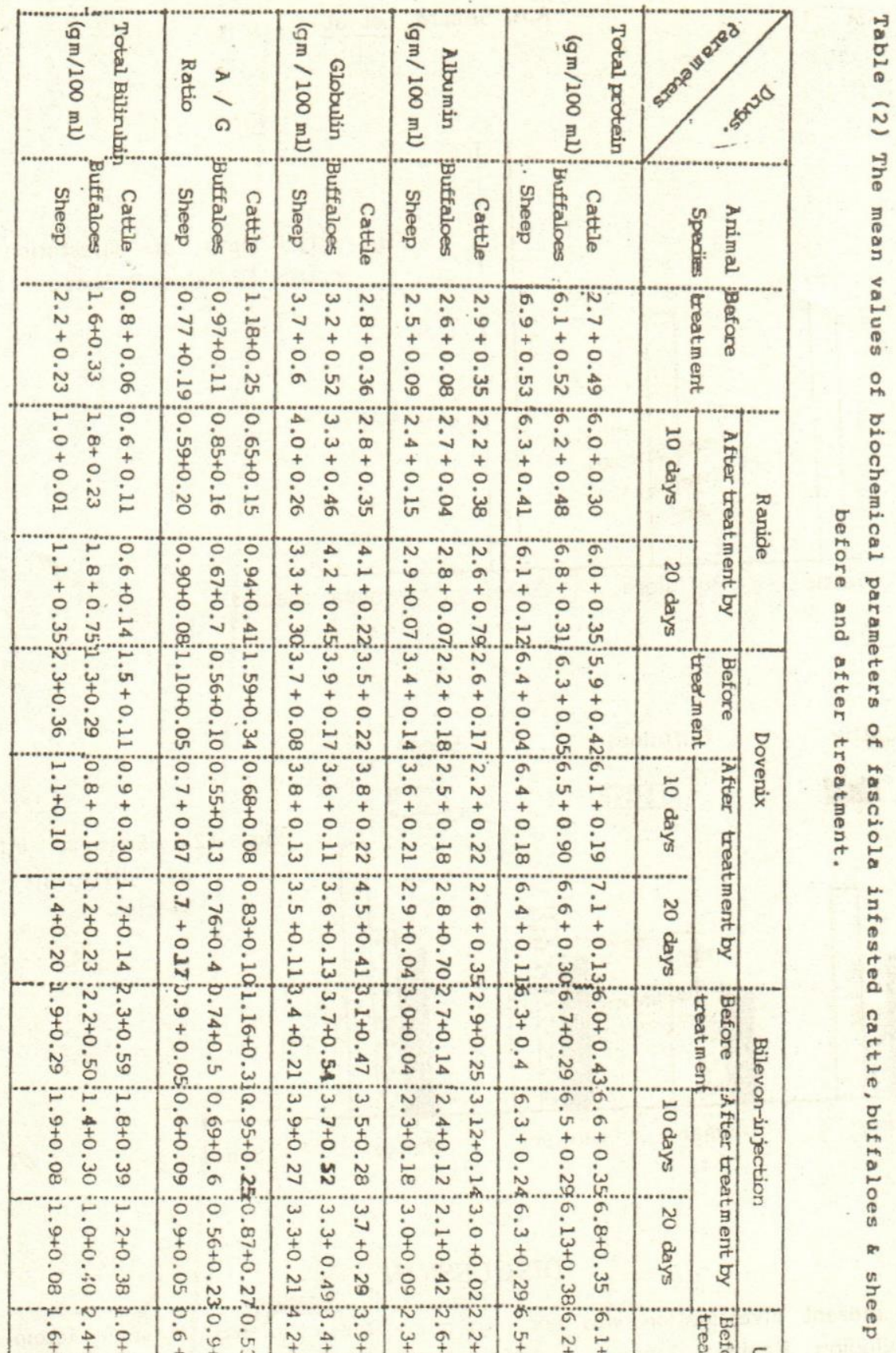


A.A. SALEM, et al.
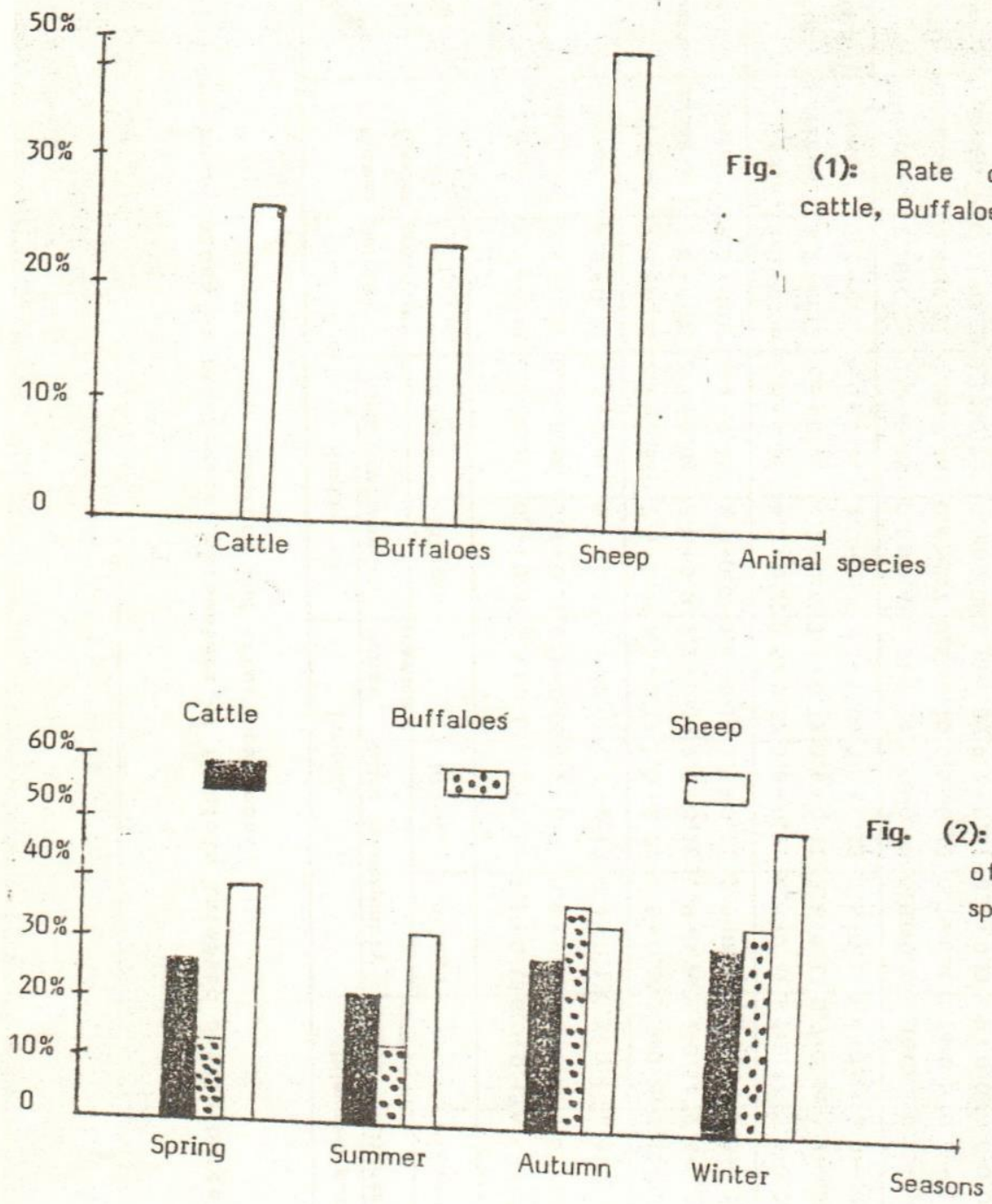

\section{DISCUSSION}

The present investigation was done to study the efficiancy of some fasciolicidial drugs inculoding Ranide, Dovenix and Bilevon-irijection on infested cattle, buffaloes and sheep. The results revealed that Dovenixsi more effective in treatment of cattle \& buffaloes; while in sheep Bilevon-injection was more efective after 2 weeks posttreatment as proved by feacal eg count. These results agree with those of AYOUB, et al. (1973) and MARU, et al. (1983). 


\section{FASCIOLA IN MID-EGYPT}

It is of importance to record that no side effects, were recorded among animals treated by Dovenix and their was no species variations in response for treatment by Bilevon-injection, these findings are previously reported by AZIZ (1980) and EL-SHERIF and FAHMY (1981).

The results of biochemical analysis revealed evidence of hypoalbuminia, hyperglobulnoemia and reduction of $A / G$ ratio in treated animals by using Ranide, Dovenix and Bilevon-injection after 10-20 days post-treatment. The results indicated a significant decrease in blood serum albumin of non-treated animals. In animals treated by these 3 drugs non significant increase in albumin could be detected. While in buffaloes treated by Dovenix and Bilevon-injection a significant increase in albumin was detected. The total protein was significently increased after treatment by Ranide, Dovenix and Bilevon injection. Our results agree with these obtained by HAIBA and SELIM (1960); TALAT, et al. (1965); AMIN (1972); ABDOU (1976); ABDEL RAHMAN, et al. (1977); EL-DISSOUKY (1977); EL-SHERIF and FAHMY (1981) and KARRAM, et al. (1988). The authors suggested that the decrease in total protein and the albumin levels in non-treated animals or in others before treatment attributed to the damage in the livers of infested animals, therefore after treatment the progressive recovery lead to decreasing hepatities and increasing in forementioned parameter levels. Also the results of biochemical studies showed that Bilevon-injection is the best drug for treatment of fasciola infested cattle, buffaloes and sheep as revealed by recovery and divation of different blood serum parameters to normal, and this is followed by Dovenix and Ranide.

\section{REFERENCES}

Amin, M.M. (1972): Some studies on fascioliasis in cattle and buffaloes in Egypt. Thesis, M.V.Sc., Faculty of Vet. Med., Cairo Univ.

Abdel-Rahman, M.S.; Salah, M.R.; Zein El-Abdin, Y.; Attia, H.; Abdel-Aziz, M.; AbdelSami, A. and Amin, M. (1977): Efficiency of some fasciolicidal drugs on fasciola gigentica in buffaloes and cattle in Egypt with particular references to cellular and biochemical studies, Egypt. J. Vet. Sc. 14 (1), 37-49.

Abdeou, O.M. (1976): Clinical studies on liver function tests in buffaloes M.V.Sc. Thesis, Faculty of Vet. Med., Cairo Univ.

Aziz, M.A. (1980): Bilevon-injection, A new Nilofolan formulation for the control of fascioliasis. Vet. Med. Review, No. 2, 145-149.

Ayoub, A.A.M. (1983): The interpretation of different tests used for estimation of parasitic states of fasciola gigentica in Gharbia Governorate. M.V.Sc. Thesis, Fac. Vet. Med., Cairo Univ.

Ayoub, A.T.; Kadhim, J.K. and Jobbir, M.H. (1973): Treatment of fasciola gigentica in sheep. Tropical animal health \& production 5 (1): 22-26.

Doumas, D. (1971): Clinical chemical Acta 31, 87.

El-Dissouky, M.l. (1972): Haematological and biochemical studies on fasciola infested buffaloes. M.V.Sc. Thesis, Fac. Vet. Med., Cairo Univ. 


\section{A.A. SALEM, et al.}

El-Sherif, M.M.T. and Fahmy, F. (1981): The efficacy of Bilevon-injection in buffaloes with natural fasciola gigentica infestation, with particular reference to metabolic parameters. Vet. Med. Review, (1): 78-85.

Haiba, M.H. and Selim, M.K. (1960): A comparative prelimintry biochemical study on the effect of fasciola infestation in bile and serum of Egyptian buffaloes, Cows \& sheep. Z.F. Parasitenkunde 19: 535-540.

Jendrassik, L. (1938): Colorimetric determination of serum bilirubin. Biochem. Z. 297.

Karram, M.H.; Abd El All, Th.S.; Nafie, Th.S. and Ismail, M.N. (1988): Some biochemical and haematological studies on sheep naturally infested with fasciola gigantica in upper Egypt. Proc. 3rd Sci. Cong. Fac. Vet. Med., Assiut Univ., $\frac{131-138 .}{13}$

Maru, A.; K umar, M. and Pachauri, S.P. (1983): Clinico haematological studies in liver fluke infested buffaloes treated with different flukcides. Vet. Bull. 53: 4701.

Parfitt, J.W. and Banks, A.W. (1970): A method for counting fasciola eggs in cattle feaces in field. Vet. Rec. 87: 180.

Ribbeck, R. and Witzel, G. (1979): Economic losses due to fasciolasis in cattle \& sheep Monalshefte fur Vet. 34 (2): 50-61.

Tallat, F.A.; Ayoub, M.H.; Awad, Y.L.; Soliman, M.A.; Goery, M.I. and El-Molla, A.A. (1965): Electropheresis pattaren and alkaline phosphatase in cattle after treatment with carbon tetrachloride. Proc. 6th Arab. Vet. Cong., 195.

Weichelbaum, T.E. (1946): An accurate and rapid method for the determination of protein in small amount of blood serum and plasma. Am. J. Clin. Path., 18. 